\title{
THE NURSING TEAM'S ROLE IN VACCINE CARE: A SCOPING REVIEW
}

\author{
ATUAÇÃO DA EQUIPE DE ENFERMAGEM NO CUIDADO COM VACINAS: UMA \\ SCOPING REVIEW
}

\author{
Suzane Gomes de MEDEIROS ${ }^{1}$; Lilian de Andrade VIRGÍLIO²; \\ Pétala Tuani Candido de Oliveira SALVADOR ${ }^{3}$; \\ Cláudia Cristiane Filgueira Martins RODRIGUES ${ }^{3}$; Marcos Antônio FERREIRA JÚNIOR ${ }^{4}$; \\ Francis Solange Vieira TOURINHO ${ }^{5}$; Quenia Camille Soares MARTINS ${ }^{6}$; \\ Viviane Euzébia Pereira SANTOS ${ }^{7}$ \\ 1. Enfermeira. Doutora pelo Programa de Pós-Graduação em Enfermagem, Universidade Federal do Rio Grande do Norte - \\ UFRN, Natal, RN, Brasil. suzanegomesm@gmail.com; 2. Enfermeira. UFRN, Natal, RN, Brasil; 3. Enfermeira. Doutora em \\ Enfermagem. Professora da Escola de Enfermagem da UFRN, Natal, RN, Brasil; 4. Enfermeiro. Professor Adjunto da \\ Universidade Federal do Mato Grosso do Sul - UFMS, Campo Grande, MS, Brasil; 5. Enfermeira. Doutora em Enfermagem. \\ Professora Adjunta do Departamento de Enfermagem e Pós-Graduação em Enfermagem da Universidade Federal de Santa \\ Catarina - UFSC, Florianópolis, SC, Brasil; 6. Enfermeira. Professora Adjunta da Faculdade de Ciências da Saúde do Trairí - \\ FACISA/UFRN, Santa Cruz, RN, Brasil; 7. Enfermeira. Doutora em Enfermagem. Professora Adjunta do Departamento de \\ Enfermagem e Pós-Graduação em Enfermagem da UFRN, Natal, RN, Brasil.
}

\begin{abstract}
Vaccines or immunobiologicals have antigenic properties and, in public health, are considered an important strategy in the prevention and control of immuno-preventable diseases. The objective of this study was to carry out review of the nursing staff's role in vaccine care. This is a scoping review, conducted in first semester of 2017, with data collected in 17 national and international databases. To guide the evaluation of the selected materials, an instrument composed of some collection indicators was used. The final sample consisted of eight publications. The data was inserted into the Microsoft Excel 2010 Program, and analyzed in a descriptive way. The identification of a variety of actions of the nursing team in the care with vaccines was verified and grouped in: vaccine room; behavior in the vaccine room; refrigerator care; organization of vaccines inside the refrigerator; monitoring and register of changes in temperature; measures adopted with vaccines under suspect; behaviors regarding vaccines in thermal boxes; professional knowledge in the vaccine room and other important behaviors. Given this evidence, it is essential to detect factors that may compromise the quality and conservation of vaccines. For this, it is understood the need for training aimed at the professionals involved in the immunization and the importance of supervision activities in the vaccine room by the nurse.
\end{abstract}

KEYWORDS: Nursing. Vaccines. Nursing Care.

\section{INTRODUCTION}

Vaccines or immunobiologicals have antigenic properties, their administration in the body is a procedure called vaccination, a process that induces the immunization and leads to immunity. However, for a safe immunization, safety actions should be used in order to ensure the quality of these products and of the vaccine practice (BRASIL, 2014).

In public health, vaccines are considered an important strategy in the prevention/control of immuno-preventable diseases, and it represents an intervention alternative with the best cost-benefit ratio implemented until today. For this to happen, it is necessary that these thermal and photosensitive inputs are not exposed to the extreme conditions of temperature and luminosity and, thus, preserve their immunizing potency and effectiveness (OLIVEIRA; CAVEIÃO; CROSEWSKI, 2014).

In general, nursing professionals constitute the technical team directly involved in the work with these immunobiologicals. In the work exercise of this category, and in the context of their responsibilities, these workers plan, coordinate, supervise and evaluate the vaccine rooms, using techniques and instruments in order to envisage the quality of care to the population (LOPES, 2015; THOFEHRN et al., 2014).

Studies on the nursing work process in these spaces are of great relevance, since they point out deficiencies especially attributed to failures in the conservation of vaccines. It should be added that the handling and administration must be performed by trained professionals, in order to offer to individuals products in their maximum power state, as well as to apply the correct dose in the correct place, in order 
to preserve patients' safety (OLIVEIRA et al., 2013; MACEDO; BOHOMOL; D'INNOCENZO, 2015).

When working in the vaccine room, the nursing professionals have the attribution of monitoring technical and operational aspects. Therefore, they should act to avoid situations that compromise the quality of immunobiologicals, such as exposure to temperature changes; because when exposed to the heat source, it can cause losses in the stock of damaged inputs and/or vaccines, reflecting the increase in budgetary constraints and hindrances to its credibility (GOMES et al., 2016; DOMINGUES; TEIXEIRA, 2013).

It is worth mentioning that other reasons may cooperate for situations that affect the quality of the immunobiologicals administered, such as: inadequacies in the physical structure, cleaning the refrigerators without adopting standardized care; lack of maintenance and deficiency in equipment, non-compliance with the rules of cleaning and organization of the refrigerator, as well as the nonadherence of workers to the practice of temperature control (RAGLIONE et al., 2016; DEUS et al., 2016).

All these factors can have an impact on the waste of resources and important doses offered in the basic care network, at the risk of maintaining vaccination coverage. In order to mitigate such events and to collaborate with the efficacy of immunobiologicals, it is pertinent that the methods and norms for their conservation and management are fulfilled (PEREIRA et al., 2013; FOSSA et al., 2015).

By adopting these precautionary measures, the professionals contribute to the maintenance of the quality of the vaccines, since it is important that the vaccination activity be permeated with care. In view of this context, the operationalization with these products should be as adequate as possible, in order to maintain the optimal potency and conditions of the immunobiologicals, besides avoiding post-vaccination reactions, in which the nursing professionals must recognize and follow the technical and theoretical aspects in the daily practice of immunization (DEUS et al., 2016; BARROS et al., 2015).

From what has been presented, this study was guided by the following question: how does the nursing team work in the immunobiological care? Therefore, it is hypothesis that nursing care with vaccines is essential to maintain the quality of these products. Like this, this study aimed to carry out review of the nursing staff's role in vaccine care.

\section{MATERIAL AND METHODS}

It is a Scoping Review elaborated through the methodology developed by Joanna Briggs Institute, Reviewer's Manual and theoretical recommendations by Arksey and O'Malley (JBI, 2015; ARSKEY; O'MALLEY, 2005). In this type of review, a collection of scientific evidence about a particular topic is made, in order to identify the concepts in a specific field of study. With this, it is possible to guide the practice and locate vulnerabilities in the productions with the perspective of contributing to science (JBI, 2015).

In the scope review, the question is formulated by the PCC strategy: P - Population; C Concept; C - Context. In this study, P - Nursing team; C - Nursing care and C - Vaccines. With this mnemonic combination, the guiding question is defined: how does the nursing team work in the immunobiological care?

The manual of Joanna Briggs Institute (2015) advocates that the initial step of the research is done by choosing the Medical Subject Headings (MeSH) for the PCC items as a means to identify the key descriptors and keywords adopted in the productions that discuss the research topic. This location is done through the National Library of Medicine (PubMed) and the Cumulative Index to Nursing and Allied Health Literature (CINAHL).

Then, to formulate the search strategy, the indexed descriptors were listed: $\mathrm{P}-$ Nursing team (\#1); C - Nursing care (\#2); C - Vaccines (\#3). The Boolean operator "AND" was used. In this way, for the databases CINAHL and PubMed it was adopted: \#1 AND \#2 AND \#3. With this strategy, initially, it was not possible to locate articles within the theme. Therefore, the search for the keywords had to be adapted, and for each base, the MeSH were used separately.

Therefore, at CINAHL, we found: (\#1): 1.014; (\#2): 33.493 and (\#3): 16.880 available articles. In PubMed the same pattern was performed, with, (\#1): 2.822; (\#2): 30.796; (\#3): 38.728 documents. This process was important and had the purpose of obtaining adequate synonyms to compose each item of the PCC.

Thus, the final strategy was formulated and the Boolean operators "AND" and "OR" used, as presented: P - (MeSH OR Keywords) AND C (MeSH OR Keywords) AND C - (MeSH OR Keywords). In this way, it resulted in: (Nursing team OR Nurse Practitioners OR Nurse OR Nursing OR Nursing Staff OR nursing assistant OR nurse staffing OR Integrated nursing) AND (Nursing Care OR Nursing Assistance OR Professional Practice 
OR Nurse's role OR Nursing practice OR Patient care management OR Nursing process) AND (Vaccines OR Immunization OR Immunization Programs OR Vaccination OR Vaccinology OR vaccine delivery $O R$ vaccine safety $O R$ vaccine adverse events OR Cold chain OR vaccine technology OR Vaccination campaign OR Immunization Schedule OR Vaccine Storage).

With this, the search in the databases of Web of Science, CINAHL, CENTRAL Cochrane, PsycINFO, Latin American and Caribbean Literature in Health Sciences (LILACS), Educational Resources Information Center (ERIC), PubMed, and SCOPUS was started. This step was carried out in the Portal of Periodicals of the Coordination for the Improvement of Higher Education Personnel (CAPES), from the Federated Academic Community (CAFe); through the institution of higher education Universidade Federal do Rio Grande do Norte (UFRN).

The gray literature from the following databases was also used: Brazil - Thesis and Dissertations Portal for the Coordination of Improvement of Higher Education Personnel (CAPES); Portugal - Scientific Repository of Open Access of Portugal (RCAAP); South African
MEDEIROS, S. G. et al.

National Theses and Dissertations (ETD Portal); World - Cyberthesis; Australia and New Zealand The National Library of Australia's Trobe (Trove); European Continent - Europe E-theses Portal (DART); Canada - Theses Canada; United Kingdom - Eletronic Theses Online Service (EThOS); Sweden and other Scandinavian countries - Academic Archive Online (DIVA). The entire search took place in first semester of 2017.

For the selection of materials, the time limit was not established, and the inclusion criteria adopted were: surveys and systematic reviews published in full in Portuguese, Spanish or English; which investigate the nursing staff's role in vaccine care. Editorials, reports of experience, theoretical essays, reflection studies, books, manuals, protocols and other revisions, as well as researches that do not present abstract and online text in full were excluded.

In the collection, the articles found were pre-selected from the reading of the titles and abstracts. For the materials that were inserted in the thematic of interest, the reading was done in full in order to identify the ones that would be included, according to Figure 1.

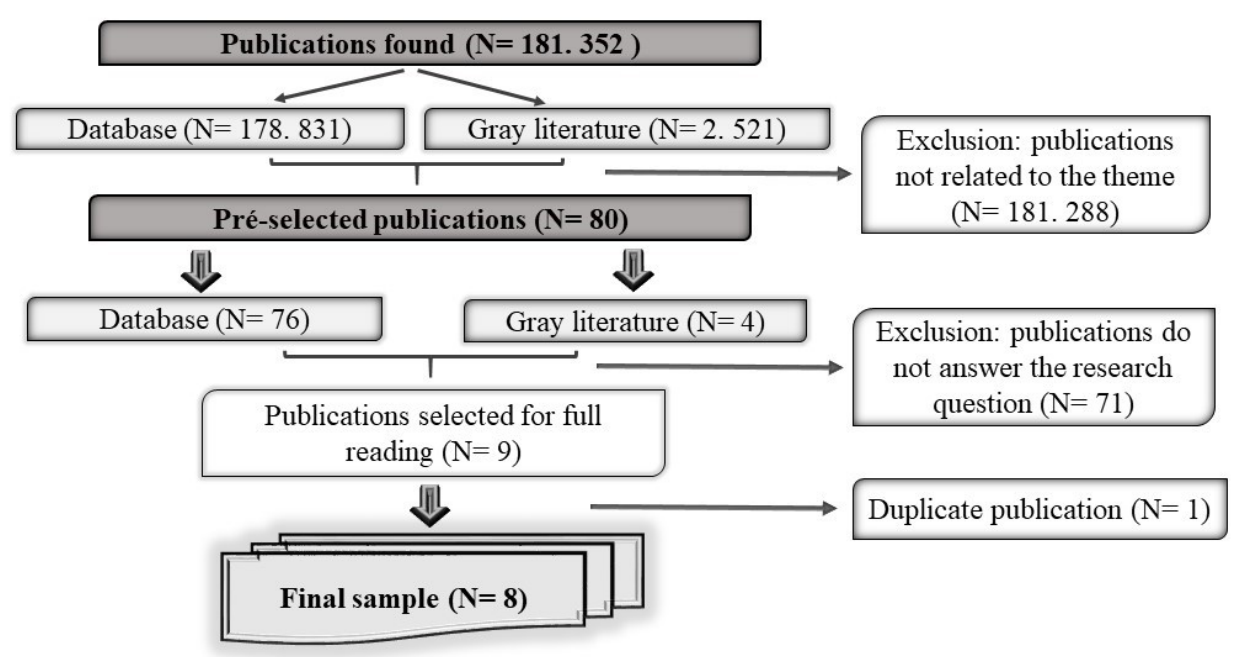

Figure 1. Flowchart for selecting publications in the databases, Natal/RN, 2018.

The instrument that was adopted to guide the evaluation of the selected materials in the final sample was composed of some indicators such as: title, database, type of study (if article, dissertation or thesis), year of publication, country where the study was carried out, purpose, population (nursing professionals who participated in the research), major vaccine care, and implications and final recommendations.
All the included articles were inserted in spreadsheets of the Microsoft Excel 2010® program, and the synthesized data analyzed descriptively, using tables and/or charts, when pertinent. The ethical appreciation was not necessary because the publications used were in the public domain. 


\section{RESULTS}

The materials selected to compose this scope review are composed of articles, dissertations and thesis, with a final sample composed by eight publications, categorized by title, type of study, year, country and database, according to Table 1.

Table 1. Characterization of publications from the title, type of study/year of publication, country in which it was carried out and the database in which it was found. Natal/RN, 2018.

\begin{tabular}{|c|c|c|}
\hline Title & $\begin{array}{l}\text { Type of } \\
\text { study/Year/Country }\end{array}$ & Database \\
\hline $\begin{array}{l}\text { Evaluation of the quality of vaccines conservation in primary healthcare } \\
\text { (OLIVEIRA et al., 2014). }\end{array}$ & Article/2014/Brazil & PUBMED \\
\hline $\begin{array}{l}\text { Aspects related to the administration and conservation of vaccines in } \\
\text { health centers in the Northeast Brazil (LUNA et al., 2011). }\end{array}$ & Article/2011/Brazil & PUBMED \\
\hline Nursing practice in vaccine conservation (OLIVEIRA et al., 2009). & Article/2009/Brazil & $\begin{array}{l}\text { WEB OF } \\
\text { SCIENCE }\end{array}$ \\
\hline $\begin{array}{l}\text { "Rede Frio" for the conservation of vaccines in public units of the city } \\
\text { of São Paulo: knowledge and practice (ARANDA; MORAES, 2006). }\end{array}$ & Article/2006/Brazil & $\begin{array}{l}\text { WEB OF } \\
\text { SCIENCE }\end{array}$ \\
\hline $\begin{array}{l}\text { Practice nurses best protect the vaccine cold chain in general practice } \\
\text { (CARR; BYLES; DURRHEIM, 2009). }\end{array}$ & $\begin{array}{l}\text { Article } / 2009 / \\
\text { Australia }\end{array}$ & CINAHL \\
\hline $\begin{array}{l}\text { Assessment of the "Rede Frio" Network of João Pessoa's Sanitary } \\
\text { District III - PB (CABRAL, 2013). }\end{array}$ & $\begin{array}{l}\text { Dissertation/ } \\
\text { 2013/Brazil }\end{array}$ & RCAAP \\
\hline $\begin{array}{l}\text { Evaluation of the quality of vaccine conservation in the Primary } \\
\text { Healthcare Units of the Central-West Region of Minas Gerais } \\
\text { (OLIVEIRA, 2012). }\end{array}$ & $\begin{array}{l}\text { Thesis/2012/ } \\
\text { Brazil }\end{array}$ & RCAAP \\
\hline $\begin{array}{l}\text { Care production of nursing team in immunization services in family } \\
\text { healthcare (OLIVEIRA, 2014). }\end{array}$ & $\begin{array}{l}\text { Dissertation/ } \\
\text { 2014/Brazil }\end{array}$ & CAPES \\
\hline
\end{tabular}

The temporal dimension of the studies was from 2006 to 2014, in which 2014 presented two $(25.0 \%)$ productions/year. Regarding the databases, there were two $(25.0 \%)$ surveys included in the RCAAP, 2 (25.0\%) in PUBMED and two (25.0\%) in the Web of Science. The articles were majority, with five $(62.5 \%)$, followed by two dissertations $(25.0 \%)$ and one thesis $(12.5 \%)$.

With seven publications, Brazil (87.5\%) was the country with an expressive majority of researches. When analyzing the productions, 4 $(50.0 \%)$ studies used the nursing team as a population of their research. One (12.5\%) publication was found in the space of the vaccine rooms, one $(12.5 \%)$ with the nurses/auxiliaries; one $(12.5 \%)$ with the nursing team/managers/users, and one $(12.5 \%)$ with the virtual environment.

Among the researches, 2 (25.0\%) had their study objectives aimed at evaluating the quality of vaccine conservation. Regarding the care of these products, Table 2 presents the diversity of measures adopted by the nursing team, according to the selected studies.

Table 2. Actions of the nursing team in vaccine care from the selected publications ( $N=8), N a t a 1 / R N, 2018$.

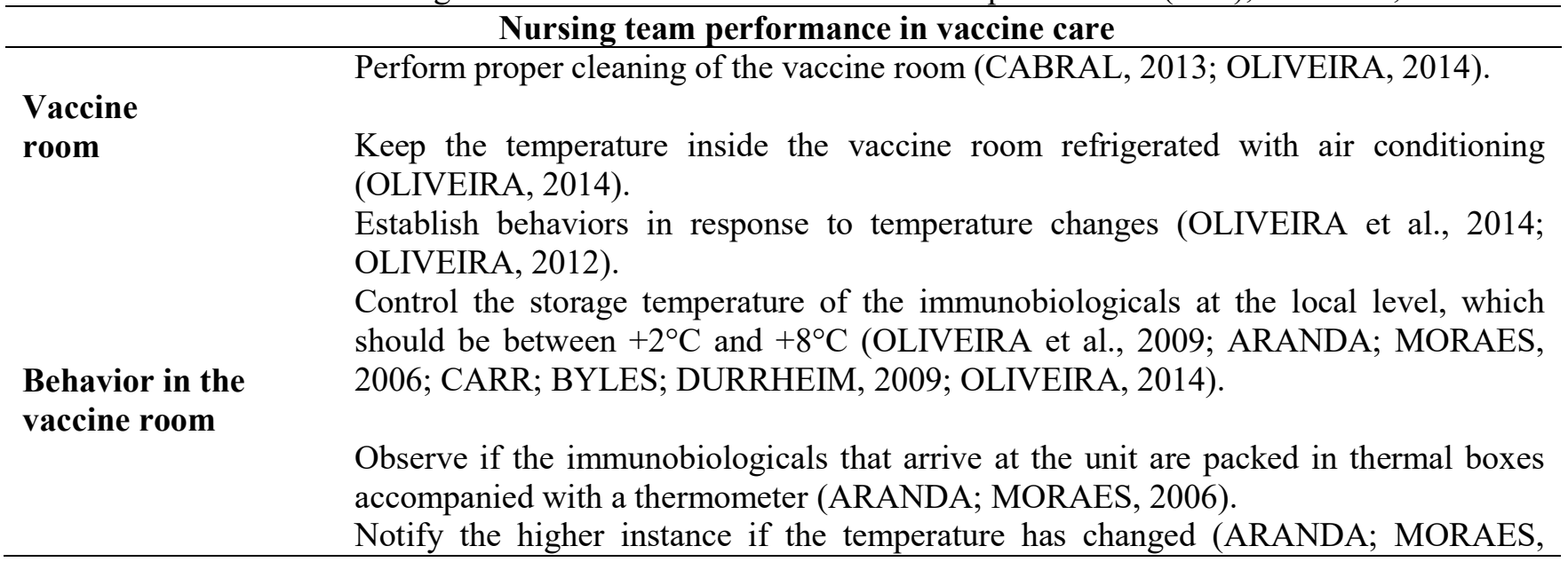




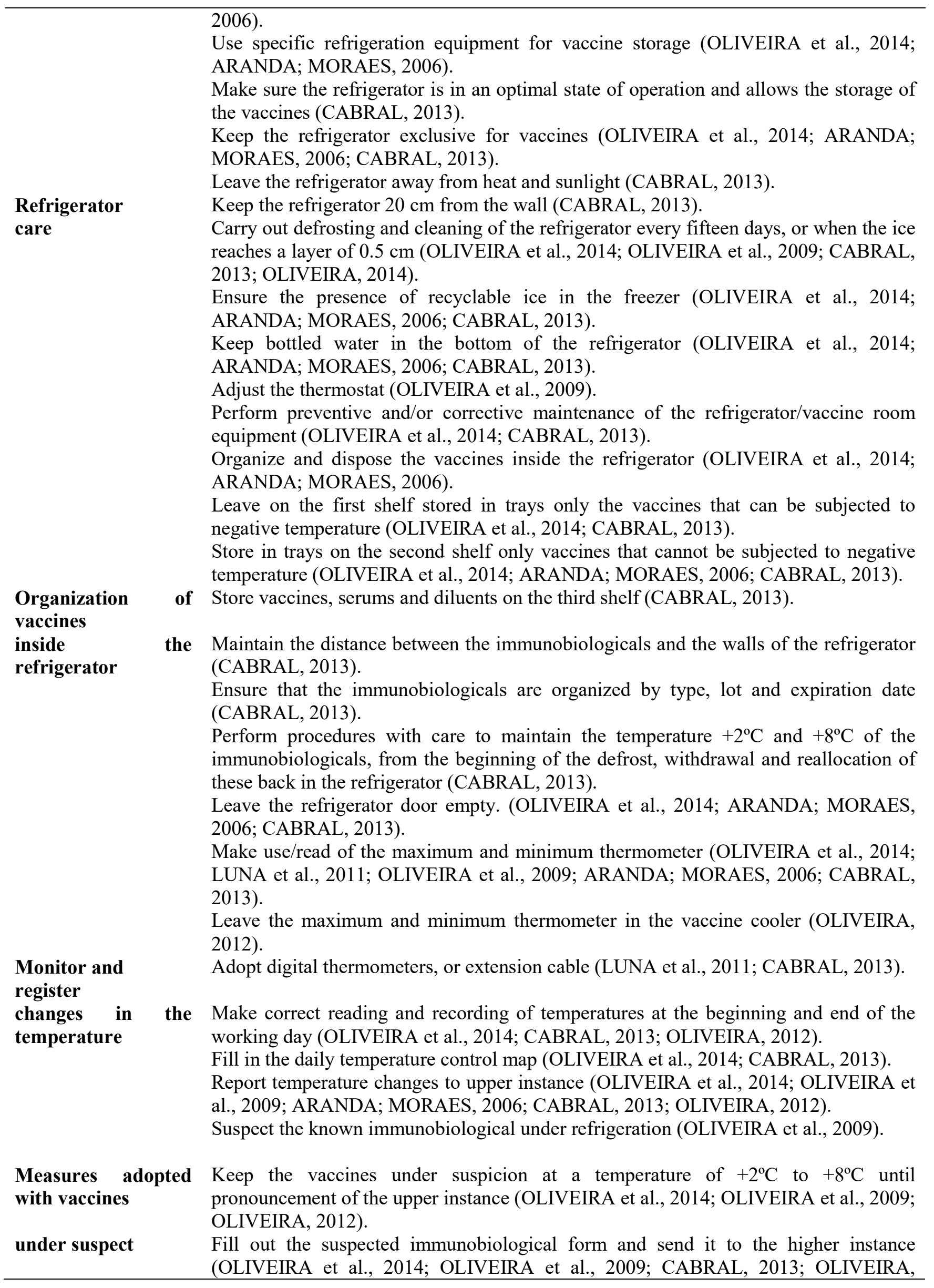


2012).

Behaviors regarding Realize the setting of recyclable ice coils (OLIVEIRA et al., 2014; OLIVEIRA et al., 2009; CABRAL, 2013; OLIVEIRA, 2012).

vaccines in thermal boxes

\author{
Knowledge of \\ the \\ professionals \\ in the vaccine \\ room
}

\section{Other \\ important behaviors}

Monitor the temperature of the thermal box or of the equipment for daily use (OLIVEIRA et al., 2014; CABRAL, 2013; OLIVEIRA, 2012).

Have knowledge about the inactivation of immunobiologicals by freezing (OLIVEIRA et al., 2009; ARANDA; MORAES, 2006).

Understand that no PNI vaccine should be frozen at the local level (OLIVEIRA et al., 2009).

Know the shelf life of the vaccines after reconstitution/dilution (OLIVEIRA et al., 2009)

Carry out training in vaccine room (OLIVEIRA et al., 2014; ARANDA; MORAES, 2006; CARR; BYLES; DURRHEIM, 2009; CABRAL, 2013; OLIVEIRA, 2014).

Provide enough material in the vaccine room (LUNA et al., 2011; CABRAL, 2013).

Condition and store syringes and needles for daily use (CABRAL, 2013).

Have a registration form (ARANDA; MORAES, 2006; CABRAL, 2013).

Perform hand hygiene (LUNA et al., 2011).

Recognize post-vaccine reactions (LUNA et al., 2011).

Have literature available in the vaccine room for possible consultations (LUNA et al., 2011).

Keep the instructional technical manual that accompanies each equipment in the vaccine room (ARANDA; MORAES, 2006).

Use only one electrical outlet for each equipment (CABRAL, 2013).

Leave a warning not to disconnect the circuit breaker of the vaccination room

(CABRAL, 2013).

Supervise the vaccine room daily (CABRAL, 2013; OLIVEIRA, 2014).
In general, the articles reinforce the need for training of the professionals working in the vaccination rooms, as well as the importance of supervision in these spaces by the nurse. Some studies emphasize the scarce publications that address the practice of nursing in the proper conservation of immunobiologicals.

\section{DISCUSSION}

From the results found, it is noticed that research on nursing care with vaccines is still incipient, which reflects concern regarding this context (OLIVEIRA et al., 2014; OLIVEIRA et al., 2009). It is known that these professionals are mainly responsible for the practice of immunization, from administration to the conservation of immunobiologicals, with these actions performed in the vaccination rooms.

Thus, the data from the selected materials and referring to the nursing staff's role in vaccine care are grouped according to Table 2 . This process allows the understanding of the various aspects that permeate the vaccine practice, based on the specific discussion of each item, according to what was evidenced in the selected materials.

\section{Vaccine room}

These spaces should be unique to vaccine activities, so the vaccine room environment needs to be cleaned properly (CABRAL, 2013; OLIVEIRA, 2014). This task is assigned to the nursing team that acts in the immunization, and must happen so that the cleaning of the room is performed every fifteen days.

In order to maintain the quality of these products, another important factor that needs to be respected is the internal temperature of the room (OLIVEIRA, 2014). This essential aspect requires that air conditioners are in perfect working conditions to ensure a satisfactory ambient temperature in order to prevent the immunobiologicals from being exposed to extreme temperatures (CABRAL, 2013).

It is believed that only vaccine rooms with appropriate infrastructure are not sufficient to ensure the quality of immunobiologicals. It is necessary that other measures collaborate for this, as the conduct carried out in these spaces by health professionals.

\section{Behavior in the vaccine room}

From the analysis of the selected materials, it is understood that establishing correct procedures 
for temperature changes are essential for the proper conservation of vaccines (OLIVEIRA et al., 2014; OLIVEIRA, 2012).

For this, it is important to control the storage temperature of the immunobiologicals at the local level, which must remain between $+2^{\circ} \mathrm{C}$ e $+8^{\circ} \mathrm{C}$, limit considered adequate to preserve the immunizing capacity of these inputs (OLIVEIRA et al., 2009; ARANDA; MORAES, 2006; CARR; BYLES; DURRHEIM， 2009; CABRAL， 2013; OLIVEIRA, 2014). In addition, it is necessary for the professional who is involved in the immunization to observe, upon receipt and supply of the products in the health unit, if they are packed in thermometers accompanied by a thermometer, to guarantee a temperature within the recommended range (ARANDA; MORAES, 2006).

If this standardization in storage temperature is altered, it is important to notify the higher level, which should be standard for all the institutions that practice vaccination.

\section{Refrigerator care}

Caring for the refrigerator should also be a priority. In this way, it is important to use specific equipment for the conservation of vaccines, such as special refrigerators and more advanced technology than domestic refrigerators, in order to promote the quality of the products (OLIVEIRA et al., 2014; ARANDA; MORAES, 2006).

Although the domestic refrigerators have a lower cost, they are not designed to maintain the ideal temperature to conserve vaccines, since they do not present uniformity in the thermal distribution, which can compromise the reliability of these products (OLIVEIRA et al., 2014). These common refrigerators may store vaccines, provided that they are kept in proper working condition and have a capacity of 280 liters or more (CABRAL, 2013).

By analyzing the productions, it was possible to observe the emphasis given to the refrigerator being exclusively for vaccines (OLIVEIRA et al., 2014; ARANDA; MORAES, 2006; CABRAL, 2013). This attitude of storing in the refrigerator only immunobiologicals avoids risks to these products, both of contamination and exposure to temperature variations (OLIVEIRA et al., 2014).

In order to avoid such temperature fluctuations, it is necessary to leave the refrigerator away from heat sources, and at any time of the day these appliances should be subject to sunlight. It should also be highlighted that in order to preserve the quality of the vaccines inside the refrigerators, this device must be kept at a distance of $20 \mathrm{~cm}$ from the wall, so that the efficacy of the vaccines is not compromised due to high temperatures (CABRAL, 2013).

Thus, in addition to taking care of the refrigerator on the outside, it is necessary that some aspects inside it are adopted. The studies of Oliveira et al., (2014); Luna et al., (2011); Cabral (2013) and, Oliveira (2014), reinforce the need to defrost and clean the refrigerator every fifteen days, or when the ice layer reaches $0.5 \mathrm{~cm}$; this is an essential technique for optimum conditions of the vaccine to be maintained as Oliveira et al. (2009) points out, because it allows the adequate temperature and conservation of these inputs. In turn, Cabral (2013) believes that the accumulation of ice in this equipment can influence the ineffective refrigeration of the immunobiologicals, due to the inappropriate circulation of air inside, with impairment to the quality of the products.

The publications of Oliveira et al., (2014); Aranda; Moraes (2006), and Cabral (2013) point to the need to use recyclable ice packs in the refrigerator. In addition, it is important to leave bottles with water in the bottom of the refrigerator, as they contribute to maintain its internal temperature between $+2^{\circ} \mathrm{C}$ and $+8^{\circ} \mathrm{C}$ in case of a lack of electric energy (OLIVEIRA et al., 2014; ARANDA; MORAES, 2006; CABRAL, 2013).

Another factor that requires attention is the setting of the thermostat in the refrigerator (OLIVEIRA et al., 2009). Its emphasis is to avoid that, at night, the back of the first shelf reaches negative temperatures. Therefore, it is pertinent to perform preventive and/or corrective maintenance of the refrigerator/equipment of the vaccine room, as a way to enable the quality of the immunobiologicals. (OLIVEIRA et al., 2014; CABRAL, 2013).

\section{Organization of vaccines inside the refrigerator}

The conservation of the ideal properties of vaccines can be benefited from the correct organization and disposal of these inputs inside the refrigerator, a behavior that allows the internal circulation of the air in the equipment (OLIVEIRA et al., 2014; ARANDA; MORAES, 2006). Thus, in the first shelf, only the vaccines that can be subjected to the negative temperature must be stored (OLIVEIRA et al., 2014; CABRAL, 2013). Vaccines stored on this shelf should be placed in trays as they allow the retention of cold air between these products (CABRAL, 2013).

Likewise, on the second shelf are stored the vaccines that cannot be subjected to negative temperatures. (OLIVEIRA et al., 2014; ARANDA; 
MORAES, 2006; CABRAL, 2013). Thus, there is a need for the vaccines to be distributed in the refrigerators according to their thermostability, that is, on that shelf are those containing adjuvants (OLIVEIRA et al., 2014). Then, on the third shelf, the serum and diluents are stocked (CABRAL, 2013).

It is worth mentioning that such immunobiologicals need to be maintained at some distance from the walls of the refrigerator in order to allow the circulation of the cooled air satisfactorily within the apparatus. Thus, it is imperative that immunobiologicals are organized by type, lot and expiration date. This provision of the products enables that the vaccines with the closest expiration date are used in advance (CABRAL, 2013).

In view of the above, the organization of the immunobiological deserves attention, and it can be done after cleaning the refrigerators. Regarding this aspect of equipment hygiene, the procedures must be carried out with due care to maintain the temperature $+2^{\circ} \mathrm{C}$ and $+8^{\circ} \mathrm{C}$ of the immunobiologicals from the beginning of the defrost to the withdrawal and replacement of these products back to the refrigerator (CABRAL, 2013).

During the vaccines placement, a recommendation is made that no products should be placed in the refrigerator door, which should remain empty. This criterion must be adopted because products stored in this place are very exposed to temperature variations, which contributes to the loss of their effectiveness (OLIVEIRA et al., 2014; ARANDA; MORAES, 2006; CABRAL, 2013).

\section{Monitor and register changes in the temperature}

As a way to avoid changes in the quality of vaccines, it is essential that the daily temperature monitoring is performed by using/reading the maximum and minimum thermometer (OLIVEIRA et al., 2014; LUNA et al., 2011; OLIVEIRA et al., 2009; ARANDA; MORAES, 2006; CABRAL, 2013). This measure must be carried out routinely and, for this, it is fundamental to leave the maximum and minimum thermometer in the refrigerator of the vaccines, as a way to facilitate its visualization and to make sure of its proper conservation (OLIVEIRA, 2012).

For this monitoring of the temperature, digital thermometers can be used (LUNA et al., 2011; CABRAL, 2013). From these tools, it is possible to correctly read and record the temperatures at the beginning and at the end of the working day. (OLIVEIRA et al., 2014; CABRAL, 2013; OLIVEIRA, 2012). Following this observation, it is also recommended to fill in the daily temperature log map (OLIVEIRA et al., 2014; CABRAL, 2013). Thus, it is important to keep the daily temperature control map fixed on a visible place (CABRAL, 2013).

If changes in temperature occur, it is necessary to communicate to the hierarchically superior instance (OLIVEIRA et al., 2014; OLIVEIRA et al., 2009; ARANDA; MORAES, 2006; CABRAL, 2013; OLIVEIRA, 2012). This standard should be followed as a way to avoid the loss of vaccines and the administration of these inactivated products (OLIVEIRA, 2012).

\section{Measures adopted with vaccines under suspect}

The professional who works in the vaccine room should suspect the immunobiological that is under refrigeration out of the recommended range. This happens when the worker observes a temperature oscillation without reasons. In this case, it is recommended to suspend its use (OLIVEIRA et al., 2009). However, these vaccines should be kept at a temperature of $+2^{\circ} \mathrm{C}$ to $+8^{\circ} \mathrm{C}$ until pronounced by the upper instance (OLIVEIRA et al., 2014; OLIVEIRA et al., 2009; OLIVEIRA, 2012).

In the face of these episodes, it is important that the correct immunobiological form be filled in and sent to the higher instance. (OLIVEIRA et al., 2014; OLIVEIRA et al., 2009; CABRAL, 2013; OLIVEIRA, 2012). The compliance with these guidelines mitigates the unnecessary waste of vaccines, since the methods for measuring whether a vaccine still has the lowest potency are costly (OLIVEIRA et al., 2014).

\section{Behaviors regarding vaccines in thermal boxes}

For the studies of Oliveira et al. (2014); Oliveira et al., (2009); Cabral (2013) and Oliveira (2012), a technical device of great esteem in the conservation of immunobiologicals is the setting of the recyclable ice coil in the organization of the vaccines in thermal box. These ice coils, when retracted from the freezer, usually have a temperature around $-7^{\circ} \mathrm{C}$, and if inserted directly in the box with the vaccines, without an anticipated temperature control, it exposes these products to the risk of freezing, inactivating them. (OLIVEIRA et al., 2009).

In view of this aspect, the need to monitor the temperature of the thermal box or the equipment for daily use is reinforced, since these thermolable products deteriorate at room temperature and, therefore, the maintenance of adequate conditions favors the conservation of quality immunobiological studies. (OLIVEIRA et al., 2014; CABRAL, 2013; OLIVEIRA, 2012). 


\section{Knowledge of the professionals in the vaccine room}

Immunization workers need to know the conservation temperature limits, as well as know that vaccines are not stored in the freezer (ARANDA; MORAES, 2006). Likewise, these professionals should have knowledge about the inactivation of immunobiologicals by freezing, since no vaccines at the local level should be subjected to this extreme cooling process. (OLIVEIRA et al., 2009; ARANDA; MORAES, 2006). For this, it is imperative that the human resources responsible for this sector know the possibilities of inactivating the products they deal with daily, and know the expiration time of the vaccines after reconstitution/dilution; since vaccines in general must be used for a given time after their dilution or opening (OLIVEIRA et al., 2009).

In this perspective, five publications Oliveira et al., (2014); Aranda; Moraes (2006); Carr; Byles; Durrheim (2009); Cabral (2013), and Oliveira (2014), emphasize the importance of vaccine room training. These trainings contribute in a positive way in the execution of correct procedures for the conservation of vaccines. However, there is still a need for greater emphasis on the theoretical knowledge that permeates this practice (ARANDA; MORAES, 2006). Similarly, Carr; Byles; and Durrheim (2009) believe that specific education in immunization influences nursing professionals to perform their actions safely and effectively, and that the best form of training is through permanent health education, according to Cabral (2013).

\section{Other important behaviors}

According to Luna et al. (2011) and Cabral (2013), in order to meet the demands of users seeking immunization services, the health professionals must provide sufficient materials in vaccine rooms. Thus, the immunobiologicals themselves, needles, syringes, office supplies, among others (LUNA et al., 2011) are needed. Thus, in addition to securing stockpiles, syringes and needles must be properly packed in clean, capped containers and stored in tightly closed containers and in a non-humid place (CABRAL, 2013). It is also understood the need to have a registration form, as well as the organization of the working material (ARANDA; MORAES, 2006; CABRAL, 2013).

Keeping inputs organized requires wellstructured vaccine rooms to help ensure that the immunobiologicals are safely administered. For this safety, it is also essential that the vaccine rooms have a sink, disposable towel and soap. With this, the health worker who is involved in the vaccination process must perform the hygiene of the hands, as well as know how to recognize post-vaccine reactions in the users (LUNA et al., 2011).

As a way to facilitate the identification of these post-vaccine reactions, it is important that the vaccine rooms have available literature on the aspects that involve immunization, so that professionals can consult them when necessary. These materials can be composed of technical reports, books, online publications, manuals, among others (LUNA et al., 2011). It is also advisable to maintain the instructional technical manual that accompanies each equipment in the vaccine room, especially upon the arrival of new specific devices for the conservation of vaccines (ARANDA; MORAES, 2006).

Another essential measure to maintain the conditions of these products is to use electrical outlets of exclusive use for each equipment in vaccine room. This fact must be considered so that there is no overload of the electric source to the refrigerator, a circumstance that can damage the preservation of the immunobiologicals. In order to avoid setbacks in the distribution of the electricity, it is advisable to leave a warning not to disconnect the circuit breaker from the vaccination environment (CABRAL, 2013).

It is highlighted the importance of daily supervision in the vaccine room by the nurse (CABRAL, 2013; OLIVEIRA, 2014). In this process, this professional is required to have a technical responsibility for the service, as well as an understanding of the entire context for vaccination activities.

\section{CONCLUSIONS}

The results allow the identification of a diversity of actions adopted by nursing to favor the quality of immunobiological, through actions directed to the vaccine room; cleaning of the refrigerator; the organization of vaccines inside the equipment for its conservation; the monitoring of the temperature of the immunization room; refrigerators and vaccines; the use of vaccines in thermal boxes; among others.

It is understood that all these aspects are important for the quality of the vaccines. However, it is worth noting the need for training aimed at workers in this sector and the importance of nurses in supervising the activities carried out in the immunization environment.

As a limitation of the study, the low amount of materials found in the gray literature, in which 
some databases did not provide any study of interest for this investigation should be highlighted. However, the scope review presented allows a mapping of the nursing action regarding the vaccines, in the sense of making possible the maintenance of their ideal properties for effective vaccination.
It is suggested that new studies are carried out in order to reduce the knowledge gaps on this subject, which need to be valued and investigated, in order to strengthen care and safety regarding the immunobiological products offered to the population.

RESUMO: As vacinas ou imunobiológicos possuem propriedades antigênicas e, na saúde pública, são consideradas uma estratégia importante na prevenção e controle de doenças imunopreveníveis. O objetivo desse estudo foi realizar revisão sobre a atuação da equipe de enfermagem no cuidado com vacinas. Trata-se de uma scoping review, realizada no primeiro semestre de 2017, com dados coletados em 17 bases de dados nacionais e internacionais. Para nortear a avaliação dos materiais selecionados, um instrumento composto por alguns indicadores de coleta foi utilizado. A amostra final foi composta por oito publicações. Os dados foram inseridos no Programa Microsoft Excel 2010 e analisados de forma descritiva. Constatou-se a identificação de uma variedade de ações da equipe de enfermagem no cuidado com vacinas, agrupadas em: sala de vacina, condutas na sala de vacina, cuidados com o refrigerador, organização das vacinas no interior do refrigerador, monitorar e registrar alterações na temperatura, medidas adotadas com vacinas sob suspeita, condutas com vacinas em caixas térmicas, saberes profissionais em sala de vacina e, outras condutas importantes. Diante dessas evidências, torna-se fundamental a detecção dos fatores que podem comprometer a qualidade e conservação das vacinas. Para isso, entende-se a necessidade de capacitações voltadas aos profissionais que atuam na imunização e a importância das atividades de supervisão na sala de vacina pelo enfermeiro.

PALAVRAS-CHAVE: Enfermagem. Vacinas. Cuidados de Enfermagem.

\section{REFERENCES}

ARANDA, C. M. S. S.; MORAES, J. C. Rede de frio para a conservação de vacinas em unidades públicas do município de São Paulo: conhecimento e prática. Revista Brasileira de Epidemiologia, v. 9, n. 2, p. 172-178, 2006. Disponível em: http://www.scielo.br/pdf/rbepid/v9n2/04.pdf

ARKSEY, H.; O'MALLEY, L. Scoping studies: towards a methodological framework. International Journal of Social Research Methodology, v. 8, n. 1, p. 19-32, 2005. Disponível em: https://www.york.ac.uk/inst/spru/pubs/pdf/Scopingstudies.pdf

\section{BARROS, M. G. M.; SANTOS, M. C. S.; BERTOLINI, R. P. T.; PONTES NETTO, V. B.;} ANDRADE, M. S. Perda de oportunidade de vacinação: aspectos relacionados à atuação da atenção primária em Recife, Pernambuco, 2012. Epidemiologia e Serviços de Saúde, v. 24, n. 4, p. 701-710, 2015. Disponível em: http://www.scielo.br/pdf/ress/v24n4/2237-9622-ress-24-04-00701.pdf

BRASIL. Ministério da Saúde. Manual de Normas e Procedimentos para Vacinação. Secretaria de Vigilância em Saúde. Departamento de Vigilância das Doenças Transmissíveis. Brasília: Ministério da Saúde, 2014. 176 p. Disponível em:

http://bvsms.saude.gov.br/bvs/publicacoes/manual_procedimentos_vacinacao.pdf

\section{CABRAL, I. C. Avaliação da Rede de Frio local do Distrito Sanitário III de João Pessoa -PB.}

João Pessoa. 2013. 87f. Dissertação (Mestrado em enfermagem) - Pós-Graduação em Enfermagem, Universidade Federal da Paraíba, João Pessoa, 2013. 
CARR, C.; BYLES, J.; DURRHEIM, D. Practice nurses best protect the vaccine cold chain in general practice. Australian Journal of Advanced Nursing, v. 27, n. 2, p. 35-39, 2009. Disponível em: http://www.ajan.com.au/vol27/carr.pdf

DEUS, S. E. M.; MARQUES, A. D. B.; TEIXEIRA, J. C. L.; DEUS, P. R. M.; MORAES, M. E. A.; MACEEDO, D. S. Estudo dos procedimentos quanto à conservação das vacinas do Programa Nacional de Imunização. Revista de enfermagem UFPE, v. 10, n. 3, p. 1038-1046, 2016. Disponível em: http://www.revista.ufpe.br/revistaenfermagem/index.php/revista/article/view/8465/pdf_9853

DOMINGUES, C. M. A. S.; TEIXEIRA, A. M. S. Coberturas vacinais e doenças imunopreveníveis no Brasil no período 1982-2012: avanços e desafios do Programa Nacional de Imunizações.

Epidemiologia e Serviços de Saúde, v. 22, n. 1, p. 9-27, 2013. Disponível em:

http://scielo.iec.pa.gov.br/pdf/ess/v22n1/v22n1a02.pdf

FOSSA, A. M.; PROTTI, A. M.; ROCHA, M. C. P.; HORIBE, T. M.; PEDROSO, G. E. R. Conservação e administração de vacinas: a atuação da enfermagem. Saúde em Revista, v. 15, n. 40, p. 85-96, 2015. Disponível em: http://www.bibliotekevirtual.org/revistas/Metodista-

NIMEP/SR/v15n40/v15n40a07.pdf

GOMES, R. N. S.; PORTELA, N. L. C.; PEDROSA, A. O.; CUNHA, J. D. S.; MONTE, L. R. S.; SANTOS, C. N. C. Avaliação físico-funcional de salas de vacinas da rede pública municipal de Caxias-MA. Revista de pesquisa cuidado é fundamental online, v. 8, n. 1, p. 3793-3802, 2016. Disponível em: http://www.seer.unirio.br/index.php/cuidadofundamental/article/view/4046/pdf_1792

JOANNA BRIGGS INSTITUTE. Joanna Briggs Institute Reviewer's manual: 2015 edition/supplement. The University of Adelaide, Austrália: JBI; 2015. Disponível em: https://joannabriggs.org/assets/docs/sumari/Reviewers-Manual_Methodology-for-JBI-ScopingReviews_2015_v2.pdf

LOPES, A. A. F. Cuidado e Empoderamento: a construção do sujeito responsável por sua saúde na experiência do diabetes. Saúde e Sociedade, v. 24, n. 2, p. 486-500, 2015. Disponível em: http://www.scielo.br/pdf/sausoc/v24n2/0104-1290-sausoc-24-02-00486.pdf

LUNA, G. L. M.; VIEIRA, L. J. E. S.; SOUZA, P. F.; LIRA, S. V. G.; MOREIRA, D. P.; PEREIRA, A. S. Aspectos relacionados à administração e conservação de vacinas em centros de saúde no Nordeste do Brasil. Ciência e Saúde Coletiva, v. 16. n. 2, p. 513-521, 2011. Disponível em: http://www.scielo.br/pdf/csc/v16n2/v16n2a14.pdf

MACEDO, G. P. O. S.; BOHOMOL, E.; D’INNOCENZO, M. Terapêutica medicamentosa para criança em serviço hospitalar de emergência. Acta Paulista de Enfermagem, v. 28, n. 3, p. 237-242, 2015. Disponível em: http://www.scielo.br/pdf/ape/v28n3/1982-0194-ape-28-03-0237.pdf

OLIVEIRA, I. P. Produção do cuidado da equipe de enfermagem nos serviços de imunização na atenção à saúde da família. 2014. 132f. Dissertação (Mestrado profissional em enfermagem) - PósGraduação em Enfermagem, Universidade Estadual de Feira de Santana; Feira de Santana, 2014.

OLIVEIRA, V. C.; CAVEIÃO, C.; CROSEWSKI, F. Gerenciamento de enfermagem no controle de perdas evitáveis de imunobiológicos. Cogitare Enfermagem, v. 19, n. 4, p. 679-686, 2014.

Disponível em: http://revistas.ufpr.br/cogitare/article/view/36358/23921 
OLIVEIRA, V. C.; GALlARDO, M. D. P. S.; ARCÊNCIO, R. A.; GONTIJO, T. L.; PINTO, I. C. Avaliação da qualidade de conservação de vacinas na atenção primária à saúde. Ciência e Saúde Coletiva, v. 19, n. 9, p. 3889-3898, 2014. Disponível em: http://www.scielo.br/pdf/csc/v19n9/14138123-csc-19-09-3889.pdf

OLIVEIRA, V. C.; GALLARDO, O. S.; GOMES, T. S.; PASSOS, L. M. R.; PINTO, I. C. Supervisão de enfermagem em sala de vacina: a percepção do enfermeiro. Texto contexto Enfermagem, v. 22, n. 4, p. 1015-1021, 2013. Disponível em: http://www.scielo.br/pdf/tce/v22n4/18.pdf

OLIVEIRA, V. C.; GUIMARÃes, E. A. A.; GUIMARÃES, I. A.; JANUÁRIO, L. H.; PINTO, I. C. Prática da enfermagem na conservação de vacinas. Acta Paulista de Enfermagem, v. 22, n. 6, p. 814-818, 2009. Disponível em: http:/www.scielo.br/pdf/ape/v22n6/a14v22n6.pdf

OLIVEIRA, V. C. Avaliação da qualidade da conservação de vacina nas Unidades de Atenção Primária à Saúde da Região Centro-Oeste de Minas Gerais. 2012. 147f. Tese (Doutorado em enfermagem) - Pós-Graduação em Enfermagem em Saúde Pública, Universidade de São Paulo, Ribeirão Preto, 2012.

PEREIRA, D. D. S.; NEVES, E. B.; GEMELLI, M.; ULBRICHT, L. Análise da taxa de utilização e perda de vacinas no programa nacional de imunização. Caderno de Saúde Coletiva, v. 21, n. 4, p. 420-424, 2013. Disponível em: http://www.scielo.br/pdf/cadsc/v21n4/v21n4a10.pdf

RAGLIONE, D.; BEZERRA, G. A. M.; LOPES, M. H.; NERGER, M. L. B. R.; GUIMARÃES, T. C.; SARTORI, A. M. C. Avaliação da rede de frio para conservação de vacinas em unidades básicas de saúde das regiões Sul e Centro-Oeste do município de São Paulo em 2011-2012. Epidemiologia e Serviços de Saúde, v. 25, n. 1, p. 65-74, 2016. Disponível em:

http://www.scielo.br/pdf/ress/v25n1/2237-9622-ress-25-01-00065.pdf

THOFEHRN, M. B.; MONTESINOS, M. J. L.; ARRIEIRA, I. C.; ÁVILA, V. C.; VASQUES, T. C. S.; FARIAS, I. D. Processo de trabalho dos enfermeiros de um hospital da Espanha: ênfase nas tecnologias de cuidado. Cogitare Enfermagem, v. 19, n. 1, p. 141-146, 2014. Disponível em: http://revistas.ufpr.br/cogitare/article/view/35972/22180 